EMPOWER: Jurnal Pengembangan Masyarakat Islam

Vol. 5, No. 2, Desember 2020, hlm. 92-110

e-ISSN: 2580-0973, p-ISSN: 2580-085X

Tersedia online di: http://syekhnurjati.ac.id/jurnal/index.php/empower

Email: empowerjurnal@gmail.com

\title{
Kontribusi Komunitas Save Mugo \\ Melalui Pemberdayaan Ekonomi Kreatif Hutan Mangrove
}

\author{
Munah Herawati* \\ (Pengembangan Masyarakat Islam, Fakultas Ilmu Dakwah dan Komunikasi \\ UIN Syarif Hidayatullah Jakarta) \\ Email: munaherawati122@gmail.com
}

\section{Tantan Hermansah**}

(Pengembangan Masyarakat Islam, Fakultas Ilmu Dakwah dan Komunikasi

UIN Syarif Hidayatullah Jakarta)

Email: tantan.hermansah@uinjkt.ac.id

\section{Article History}

Submitted: 07.11.2020; Revised: 09.12.2020; Accepted: 14.12.2020;

\begin{abstract}
The mangrove forest area in Muara Gembong Bekasi has benefits for the area and the surrounding community. However, along with economic pressure from large investors, many mangrove forests have been converted into commercial areas such as ponds. As a result, some of the residents are displaced or have lost their livelihoods. Seeing this problem, the presence of the Save Mugo Community, a community group that cares about the environmental rescue movement, is quite helpful for the community to overcome several problems in this region. This study is a long observation to see how the community movement, which in this case is represented by the Save Mugo Community, in overcoming problems in their environment; as well as seeing the impact of this movement on the lives of the community partners of the program. The results of this study indicate that the contributions made by the Save Mugo Community are: (1) environmental empowerment while at the same time endeavoring to conserve the mangrove forest ecosystem; (2)
\end{abstract}


empowerment of ecotourism areas; and (3) creative economy empowerment, which is a continuation of ecotourism empowerment.

Keywords: community empowerment, creative economy, mangrove utilization

\begin{abstract}
Abstrak
Kawasan hutan mangrove di Muara Gembong Bekasi memiliki manfaat bagi daerah tersebut dan masyarakat sekitar. Namun, seiring dengan tekanan ekonomi dari investor besar, banyak hutan mangrove telah diubah menjadi area komersial seperti kolam. Akibatnya, beberapa warga mengungsi atau kehilangan mata pencaharian. Melihat permasalahan ini, kehadiran Komunitas Save Mugo, kelompok masyarakat yang peduli dengan gerakan penyelamatan lingkungan, cukup membantu masyarakat untuk mengatasi beberapa permasalahan di wilayah ini. Penelitian ini merupakan pengamatan panjang untuk melihat bagaimana pergerakan masyarakat, yang dalam hal ini diwakili oleh Komunitas Save Mugo, dalam mengatasi permasalahan di lingkungannya; serta melihat dampak dari gerakan ini terhadap kehidupan mitra masyarakat dari program tersebut. Hasil penelitian ini menunjukkan bahwa kontribusi yang diberikan oleh Komunitas Save Mugo adalah: (1) pemberdayaan lingkungan hidup sekaligus berupaya melestarikan ekosistem hutan mangrove; (2) pemberdayaan kawasan ekowisata; dan (3) pemberdayaan ekonomi kreatif, yang merupakan kelanjutan dari pemberdayaan ekowisata.
\end{abstract}

Kata kunci: pemberdayaan masyarakat, ekonomi kreatif, pemanfaatan mangrove

\title{
PENDAHULUAN
}

Hutan mangrove merupakan salah satu sumber daya alam wilayah pesisir yang mempunyai peranan penting ditinjau dari sudut sosial, ekonomi, dan ekologis ${ }^{1}$. Sebagai kawasan yang menyangga pantai, hutan mangrove memiliki banyak fungsi dalam kehidupan masyarakat sekitarnya.

1 Roberto Takarendehang et al., "Kondisi Ekologi Dan Nilai Manfaat Hutan Mangrove Di Desa Lansa, Kecamatan Wori, Kabupaten Minahasa Utara," Jurnal Pesisir Dan Laut Tropis 2, no. 1 (2018). 
Indonesia mempunyai luas mangrove sebesar 3.489.140,68 Ha. Jumlah ini setara dengan $23 \%$ ekosistem mangrove dunia yaitu dari total luas 16.530 .000 Ha.

Peranan pemerintah terhadap pemberdayaan masyarakat pesisir dalam pengembangan tanaman mangrove memperoleh skor rata-rata 49,94 termasuk kategori cukup. Partisipasi masyarakat dalam pengembangan tanaman mangrove memperoleh skor rata-rata 41,81 termasuk kategori cukup ${ }^{2}$.

Ada banyak perlakuan terhadap kawasan hutan mangrove, misalnya di Maluku, model yang yang digunakan adalah metode konservasi kawasan berbasis modal budaya $^{3}$, dan juga ada yang melakukan pengembangan mangrove dengan memanfaatkan modal sosial ${ }^{4}$. Lalu ada juga yang memadukannya dengan kearifan lokal serta dengan menerapkan prinsip win-win solution terhadap komunitas terkait. Perlindungan hutan mangrove di daerah garis pantai ${ }^{5}$.

Sementara itu di Munjang, Pengembangan ekowisata mangrove Munjang dalam setiap prosesnya senantiasa melibatkan masyarakat dan stakeholders secara optimal. Hal ini didasarkan kepada pertimbangan untuk memberikan ruang yang luas bagi masyarakat sekitar agar mendapatkan manfaat ekonomi serta sekaligus memperkuat konsep ekowisata di Munjang mangrove secara berkelanjutan ${ }^{6}$. Dengan pendekatan lain, kawasan

2 Sutrisno, "Pemberdayaan Dan Partisipasi Masyarakat Pesisir Dalam Pengembangan Tanaman Mangrove Di Kabupaten Pati," Jurnal Bina Praja 7, no. 1 (2015).

3 Salampessy et al., "Cultural Capital Of The Communities In The Mangrove Conservation In The Coastal Areas Of Ambon Dalam Bay, Moluccas, Indonesia," International Conference on Tropical and Coastal Region Eco-Development 2014, 2014.

${ }^{4}$ Sulistyorini et al., "Social Capital in Mangrove Utilization for Silvofishery: Case Study in Kutai National Park, Indonesia," Jurnal Manajemen Hutan Tropika 24, no. 2 (2018): 60-69.

${ }^{5}$ Purwowibowo and Nur Dyah Gianawati, "Kearifan Lokal Dalam Pelestarian Hutan Mangrove Melalui Community Development," Dalam Jurnal Bina Hukum Lingkungan 1, no. 1 (2016).

${ }^{6}$ Henri and Seta Ardiawati, Ecotourism Development Of Munjang Mangrove Forest And Conservation Efforts Based On Community Approach, 2020. 
mangrove dikembangkan dengan formulasi ekologis ${ }^{7}$ sehingga menjamin keberlanjutan alam, lingkungan, dan bahkan kehidupannya. Pelestarian mangrove juga dapat dilakukan dengan penggalakan kegiatan konservasi dan pengikutsertaan masyarakat.

Pengembangan berbagai penyelamatan hutan mangrove menunjukkan hal posisitf. Pada sebuah studi yang mengkaji tentang kebijakan penataan kawasan membuktikan hal tersebut. Di mana, menurut kajian tersebut, temuan studi ini memberikan peluang dapat diterapkan pada pengembangan kebijakan pengelolaan sumber daya hutan secara lestari. Secara khusus, kebijakan yang di dalamnya merancang program pengelolaan koperasi dengan meningkatkan partisipasi masyarakat lokal dalam pengambilan keputusan untuk pengelolaan hutan, maka pengelolaan hutan partisipatif tidak hanya dapat berkontribusi pada kelestarian lingkungan tetapi juga membantu membangun modal sosial masyarakat untuk meningkatkan mata pencaharian masyarakat ${ }^{8}$.

Studi lain membuktikan bahwa tingkat persepsi dan partisipasi untuk pengembangan ekowisata mangrove di Kakaralamo menunjukkan hasil yang positif yaitu mencapai $63,78 \%$. Artinya masyarakat sangat mendukung upaya tersebut ${ }^{9}$.

Setidaknya terdapat tiga faktor dalam pengambilan keputusan tentang partisipasi masyarakat dalam pengelolaan hutan mangrove, yaitu faktor pengetahuan, faktor sikap dan pengelolaan. Sedangkan pengelolaan hutan mangrove dilakukan oleh masyarakat di Kabupaten Rangsang dalam bentuk rehabilitasi, perawatan dan pengawasan. Oleh karena itu, dalam upaya pengelolaan hutan mangrove berbasis masyarakat diperlukan peran

\footnotetext{
7 Luchman Hakim, Dian Siswanto, and Nobukazu Nakagoshi, "Mangrove Conservation in East Java: The Ecotourism Development Perspectives," The Journal Of Tropical Life Science 7, no. 3 (2017): 277-85.

8 Valenzuela et al., "Local People's Participation in Mangrove Restoration Projects and Impacts on Social Capital and Livelihood: A Case Study in the Philippines," In Forest 11 (2020): 580.

9 Darius Arkwrigh and Irena Septianita Kaomaneng, "Mangrove Ecotourism Development on Kakaralamo Island North Halmahera: Community Perception, Participation and Development Strategies," IOP Conf. Series: Earth and Environmental Science 175 (2018).
} 
aktif masyarakat dengan memperhatikan faktor pengelolaan, faktor pengetahuan dan faktor sikap ${ }^{10}$.

Namun demikian, hutan mangrove bukan tanpa ancaman. Bahkan bisa dikatakan ancaman itu sudah berlangsung lama sekali. Salah satunya adalah metode "silvofishery". Silvofishery adalah sistem pertambakan teknologi tradisional yang menggabungkan antara usaha perikanan dengan penanaman mangrove, yang diikuti konsep pengenalan sistem pengelolaan dengan meminimalkan input dan mengurangi dampak terhadap lingkungan. Konstruksi tambak di Desa Arakan pada pengabdian pada masyarakat ini lebih memilih silvofishery model komplangan daripada model empang parit karena model komplangan lebih ramah lingkungan ${ }^{11}$.

Kecamatan Muara Gembong merupakan salah satu kecamatan di Kabupaten Bekasi yang terbilang miskin. Hal ini disebarkan oleh rendahnya pendidikan, infrastruktur yang buruk dan kurangnya perhatian dari pemerintah setempat. Bahkan penghasilan warga setempat yang kecil, menjadikan sebagian orang tua tidak mampu membiayai sekolah anak mereka. Pendidikan terakhir kebanyakan anak-anak di Muara Gembong hanya tamat SMA.

Pada salah satu kampung, tepatnya di Kampung Beting, mata pencaharian masyarakatnya lebih banyak petani tambak ikan yang dikelola secara tradisional. Berbeda dengan model tambak yang dikelola secara modern dan bermodal besar, para petani tambak tradisional ini memiliki pendapatan yang tidak menentu ini sehingga mereka tidak bisa memenuhi kebutuhan keluarganya. Ditambah dengan penyusutan hutan mangrove yang terjadi sejak tahun 2005 yang mengakibatkan terjadinya abrasi. Abrasi ini telah membuat masyarakat kehilangan sumber mata pencahariannya sebagai petani tambak ikan.

\footnotetext{
10 Abu Hanifah and Kamaruddin Eddiwan, "Community-Based Mangrove Forest Management Action in Rangsang Region, District of Kepulauan Meranti, Riau," 2018. ${ }^{11}$ Carolus P. Paruntu, Agung B. Windarto, and Movrie Mamesah, "Mangrove Dan Pengembangan Silvofishery Di Wilayah Pesisir Desa Arakan Kecamatan Tatapaan Kabupaten Minahasa Selatan Sebagai Iptek Bagi Masrakat," Jurnal LPPM Bidang Sains Dan Teknologi 3, no. 2 (2016).
} 
Melihat berbagai peristiwa dan dampak riilnya tersebut, beberapa pemuda Bekasi kemudian membentuk suatu kumpulan yang diberikan nama Komunitas Save Mugo. Fokus komunitas ini bergerak dibidang pemberdayaan baik dalam pelestarian lingkungan maupun dibidang ekonomi.

Komunitas Save Mugo memiliki salah satu program yang bertujuan untuk memberdayakan masyarakat yang memiliki keahlian di bidang pengelolaan makanan dengan memanfaatkan bahan baku dari tanaman mangrove. Melalui program ini komunitas Save Mugo berharap dapat meningkatkan ekonomi masyarakat setempat. Karena dilihat dari segi kebermanfaatannya pohon mangrovetidak hanya bermanfaat secara ekologi saja, tetapi juga memiliki fungsi ekonomi. secara ekonomi, pohon mangrove bisa menghasilkan kayu atau serbuk kayu, bahan kertas, arang, serta tempat wisata dan buahnya pun bisa dimanfaatkan untuk meningkatkan kesejahteraan masyarakat.

Studi ini menggunakan metode kualitatif, seperti yang dijelaskan oleh Kirk dan Miller ${ }^{12}$, yang dilakukan di Kampung Beting dan salah satu rumah warga yang merupakan tempat pembuatan olahan dari bahan dasar buah mangrove, sejak bulan Mei sampai bulan Agustus 2019. Informan dari studi ini adalah: (1) Pendiri, ketua dan anggota Komunitas Save Mugo; (2) Ibu-ibu yang tergabung dalam Kelompok Bahagia Berkarya (Kebaya); dan (3) Masyarakat desa. Dalam prosesnya studi juga dilengkapi dengan observasi langsung dan menelusuri data-data dokumen yang berkaitan dengan Komunitas Save Mugo atau masyarakatnya.

\section{HASIL DAN PEMBAHASAN}

\section{Peluang Usaha Ibu-ibu Rumah Tangga}

Adanya komunitas ini membuka kesempatan ibu-ibu rumah tangga untuk memiliki usaha bersama, dimana penghasilan dari usaha ini dijadikan sebagai pemasukan tambahan untuk kebutuhan keluarga, atau sekedar sedikit membantu suaminya dalam mencukupi kebutuhan sehari-hari.

\footnotetext{
12 Lexy J. Meleong, Metodologi Penelitian Kualitatif (Bandung: PT Remaja Rosdakarya, 1991).
} 
Terdapat kurang lebihnya sebanyak 10 sampai 13 ibu-ibu yang kini mempunyai pekerja selain menjadi ibu rumah tangga.

Ada pun usaha yang dilakukan oleh ibu-ibu ini seperti, membuat dodol, keripik daun, kacang umpet, sirup, peyek, kripik umpet, kerupuk buah, kerupuk daun, stik daun. Semua bahan dari beberapa jenis makanan tersebut dibuat dengan menggunakan mangrove sebagai bahan dasarnya, dari mulai dauh hingga buah mangrove dijadikan bahan dasar dalam pembutan produk usaha tersebut. Selain bahan dasar mangrove, ibu-ibu juga membuat olahan lain dari bahan dasar ikan seperti, dendeng, kerupuk ikan bandeng dan kerupuk ikan payus. Olahan yang berbahan ikan tersebut, merupakan bentuk kolaborasi antara ibu-ibu dengan nelayan yang merupakan suami dari salah seorang ibu-ibu yang tergabung dalam kelompok usaha.

\section{Kegiatan Sosial Masyarakat}

Dengan melakukan penanaman mangrove dipinggir pantai Kampung Beting. Hal ini akan mengurangi terjadinya abrasi yang akan menimbulkan kerusakan pada lingkungan, dan pemukiman warga yang berada disekiat pantai. Program tersebut merupakan program yang merujuk pada kegiatan sosial yang dilakukan oleh Komunitas Save Mugo, dalam rangka melestarikan ekosistem Mangrove. melaui program ini menggambarkan adanya pemberdayaan masyarakat melalui ekosistem mangrove dan dampak positif yang dirasakan oleh warga sekitar sejak adanya penanaman mangrove.

\section{Pengembangan Sarana Umum}

Selain kontribusi dibidang lingkungan, terdapat juga kontribusi dibidang sara umum seperti, jembatan, MCK umum, TPQ, transportasi berupa perahu. Jembatan yang buat oleh komunitas dan warga Kampung Beting sebanyak tiga jembatan, yang jembatan itu masing-masing satu berada di Rt 05 Rw 02, satu berada di Rt 03 Rw 02, dan satu lagi terdapat di Rt 01 Rw 06. Rw 06 merupakan tempat kawasan konserpasi lutung. Jembatan ini merupakan penghubung antara rumah warga yang jaraknya berbatsan dengan sungai. MCK umum digunakan oleh beberapa warga yang tidak 
memiliki toilet, sedangkan perahu merupakan alat tranportasi yang digunakan sebagai pengganti ambulan. Hal ini dikarenakan akses jalan di Kampung Beting yang tidak memungkinkan ditempuh dengan waktu yang cepat pada saat keadaan darurat.

\section{Pemberdayaan Lingkungan}

Terbentuknya kelompok sadar wisata (pokdarwis) yang diberi nama Alipbata merupakan gerakan yang dilakukan komuinitas Save Mugo untuk memberikan informasi terkait pentingnya mengelola alam sekitar dan memanfaatkan fotensi yang dimilki untuk meningkatkan perekonomian warga. ada pun program-program Pokdarwis ialah pembibitan, pelestarian dan pengembangan mangrove, pengelolaan dan menjaga lingkungan bagi keberlangsungan wisata, edukasi kepada wisatawan yang berkunjung, pengembangan wisata untuk peningkatan ekonomi, pembuatan cendramata khas daerah pesisir Muara Gembong, dan olahan makanan dari Mangrove atau lainnya. Dengan begitu semakin besar harapan untuk bisa mengembalikan hutan mangrove di Muara Gembong seperti sedia kala. Ada pun pohon-pohon yang tergabung dalam komunitas pohon Mangrove yang terdapat di Muara Gembong antara lain:

1. Tumbungan Mangrove; terdiri dari 23 yang didominasi oleh Apiapi (Avicenia), Bakau (Rhizophora), Pedada (Sonneratia caseolaris).

2. Tumbuhan Mangrove ikutan: terdiri dari 13 jenis flora yang didominasi oleh Bintang (Cerbera odollam), Kiser (Fimbristylis ferrginea), dan Ketapang (Terminalia catappa).

3. Tumbuhan muara air tawar: terdiri dari 11 jenis yang didominasi oleh Kiser (Fimbristylis verruginea) dan Nipah (Nypha fruticans) ${ }^{13}$.

\section{Penghasilan Tambahan Warga}

Sejak dilakukan penanaman bibit mangrove, kelompok sadar wisata Alipbata yang anggotanya terdiri dari beberapa warga kampung Beting memiliki penghasilan tambahan sebagai petani bibit mangrove. Kelompk sadar wisata Alipbata yang meyediakan bibit pohon mangrove untuk

13 “Data Progress Movement Save Mugo 2018," n.d. 
kemudian dijual kepada pihak yang ingin melakukan penanaman di Kampung Beting, seperti PT dan komunitas-komunitas lainnya.

\section{Ekowisata}

Setelah dilakukan program penanaman bibit mangrove, secara perlahan hutan mangrove di Kampung Beting Muara Gembong mulai hidup kembali. Dengan kembalinya hutan mangrove, maka kembali pula habitat hewan-hewan yang hidup di sekitar lingkungan hutan mangrove, beberapa flora dan fauna yang sempat punah akibat hilangnya hutan mangrove, kini secara perlahan mulai berkembak biak setelah menemukan habitatnya. Dengan demikian tidak jarang warga asli atau masyarakat luar Muara Gembong mulai berdatangan untuk sekedar melihat hewan-hewan tersebut. Ada pun jenis hewan-hewan tersebut antara lain:

1. Mamalia: Lutung (Trachypitecus Mauritius), dan monyet ekor panjang (Macaca fascicularis), serta hewan mamalia lainnya.

2. Burung: Kurang lebih sebanyak 158, tercatat terdapat di Muara Gembong, namun enam jenis lainnya terancam punah berdasarkan kriteria IUCN (International Union for Conservation of Union), jenis-jenis burung darat laut, raja udang, elang, burung hantu, pelatuk dan burung madu.

3. Reptil dan Amphibi: Biawak (Varanus Salvator), kadal (Mabouya multifasciata) dan Kodok buduk (Bufo melanostictus) ${ }^{14}$.

\section{Ekonomi Kreatif Kebaya}

Pemberdayaan ekonomi kreatif adalah pemberdayaan yang berkelanjutan dari program pemberdayaan lingkungan. Program pemberdayaan ekonomi kreatif ini memiliki nama kelompok yaitu Kebaya yaitu Kelompok Bahagia Berkarya dengan beranggotakan ibu-ibu rumah tangga, dalam program pemberdayaan ini bahan dasar yang digunakan adalah daun dan buah mangrove, serta terdapat juga olahan yang terbuat dari ikan. Tujuan dari pemberdayaan ini adalah untuk meningkatkan

14 "Data Progress Movement Save Mugo 2018." 
kesejahteraan warga kampung Beting memalui olahan mangrove sebagai oleh-oleh ciri khas dari Pantai Pesisir Muara Gembong.

Dengan mengenalkan Muara Gembong kepada masyarakat luas melalui ekowisata, hal ini juga dilakukan untuk mempromosikan hasil olahan mangrove yang dibuat oleh Kebaya, dan sejak bergabungnya Kebaya dengan UMKM dan IKM pemesanan pun mulai bertambah. Dengan bertambahnya pemesanan olahan mangrove, penghasilan yang didapat ibuibu Kebaya pun mulai meningkat. Penghasilan yang didapat dari hasil pembuatan olahan Mangrove, dipergunakan ibu-ibu Kebaya untuk membantu suaminya dalam mencukupi kebutuhan sehari-hari. Selain untuk membantu mencukupi kebutuhan sehari-hari, ibu-ibu Kebaya juga bisa memenuhi keinginannya sendiri. Seperti membeli kerudung, make up, membeli lemari baru atau sekedar mengikuti arisan.

Edukasi yang diberikan Komunitas Save kepada warga Kampung Beting bukan hanya memberikan perubahan pada lingkungan, tetapi juga mengubah pola pikir warga untuk kearah yang lebih maju. Hal ini dapat dilihat dari peningkatan kesadaran para orangtua untuk menyekolahkan anak-anaknya kejenjang yang lebih tinggi seperti melanjutkan pendidikan ke Universitas, bukan lagi hanya sekedar belajar sampai tingkat SMA saja atau bahkan hanya untuk sekedar bisa membaca (sampai tingkat SD saja). Kini para orangtua menyadari pentingnya pendidikan secara formal guna mewujudkan cita-cita yang dimiliki oleh anaknya.

\section{Kontribusi Komunitas Save Mugo}

Hadirnya Komunitas Save Mugo di Kampung Beting Desa Bahagia Kecamatan Muara Gembong, menimbulkan perubahan secara lingkungan, dan selain itu hadirnya komunitas ini juga memberikan kontribusi dibidang ekonomi bagi warga Kampung Beting. Pemberdayaan di Kampung Beting terjadi secara bertahap. Merujuk kepada teori pemberdayaan masyarakat menurut Subejo adalah sebagai upaya untuk memfasilitasi masyarakat, mengelola dan memberi keputusan dalam sumber daya lokal sehingga mampu mendorong masyarakat mampu dan mandiri baik secara ekonomi, ekologi dan sosial. Mayoritas masyarakat di Kampung Beting bekerja sebagai nelayan atau petani tambak yang sangat mengandalkan hasil kekayaan laut. 
Masyarakat Kampung Beting merupakan masyarakat yang pemukimannya tidak jauh dari laut, sehingga masyarakatnya dikatakan sebagai masyarakat pesisir, dan laut yang jaraknya tidak jauh dari pemukiman warga, oleh masyarakat Muara Gembong diberi nama pantai Beting. Pada awalnya masyarakat Kampung Beting cenderung mengabaikan kearifan lokal yang mereka miliki yaitu hutan mangrove. hal inilah yang membuat Komunitas Save Mugo hadir untuk mendorong, dan mengubah pola pikir masyarakat untuk menjaga lingkungan serta mampu mandiri secara ekonomi dan sosial.

Dalam upaya pembangunan masyarakat, terdapat tiga model yang digunakan yaitu locality development, social planning dan social action. Dalam pemberdayaan yang dilakukan oleh Komunitas Save Mugo dimulai dengan melibatkan warga untuk melakukan penanaman bibit mangrove, merawatnya, hingga mengajak ibu-ibu berpatisipasi dengan membuat olahan dari mangrove. yang kedua membantu masyarakat sekitar untuk memecahkan masalah lingkungannya, maka dengan itu Komunitas save Mugo membuat program yang berkelanjutan yang diawali dengan memperbaiki ekosistem mangrove, dan yang ketiga dengan membentuk kelompok sadar wisata Alipbata dan kelompok Kebaya.

Dari beberapa model tersebut, dalam upaya pemberdayaan ekonomi masyarakat yang lebih ditekankan ialah community development, karena itu maka hadirnya Komunitas Save Mugo ditengah-tengah masyarakat Kampung Beting, sangat membantu masyarakat sekitar untuk memperbaiki lingkungan yang rusak dan meningkatkan perekonomian masyarakat. Hal ini diwujudkan dengan terbentuknya kelompok sadar wisata Alipbata yang akan menjaga, dan melestarikan hutan mangrove, serta kelompok Ibu-ibu berkarya dengan nama Kebaya, dimana melalui Kebaya masyarakat mampu memperbaiki perekonomian dengan cara membuat olahan dari mangrove.

Berdasarkan hal ini, maka peneliti mengatakan bahwa Komunitas Save Mugo bertujuan melakukan pemberdayaan dibidang lingkungan, sosial dan ekonomi. Pemberdayaan dilakukan dengan memperbaiki ekosistem mangrove, program ini merupakan kegiatan sosial yang dilakukan untuk menyelamatkan dan menghidupkan kembali hutan mangrove Muara Gembong. 
Penanaman mangrove mulai dilakukan sejak tanun 2013 sampai sekarang. Dari beberapa temuan lapangan, peneliti menemukan bentuk pemberdayaan masyarakat melalui pengembangan ekowisata dan olahan yang dibuat dari mangrove. pemberdayaan tersebut merupakan hasil kontribusi Komunitas Save Mugo.

Berikut kontribusi yang dirasakan masyarakat Kampung Beting dari kehadiran Komunitas Save Mugo. Pertama, kontribusi yang berupa terbukanya peluang usaha untuk ibu-ibu rumah tangga, merupkan salah satu program pemberdayaan yang diberikan oleh Komunitas save Mugo kepada masyarakat. Membuka peluang usaha untuk ibu-ibu, merupakan tujuan untuk mengembangkan kemampuan masyarakat yang terdapat dalam model pemberdayaan masyarakat yaitu Model Pembangunan lokal (Locality Development). Hal demikian dapat membantu meningkatkan perekonomian warga dengan penghasilan yang didapatkan oleh ibu-ibu Kebaya. Dari beberapa informan yang merupakan anggota Kebaya, mengatakan bahwa dengan hadirnya komunitas ditengah-tengah masyarakat membuka peluang usaha untuk ibu-ibu.

Kedua, kontribusi yang dilakukan oleh Komunitas Save Mugo ini, selain membuka peluang usaha untuk ibu-ibu, juga terdapat kontribusi dibidang lingkungan yang juga merupakan kegiatan sosial masyarakat. Dengan penanaman bibit mangrove yang dilakukan komunitas melibatkan pemuda dan kepala keluarga Kampung Beting dalam rangka pelestarian ekosistem mangrove. Dalam kegiatan ini tidak jarang pihak PT atau pun Yayasan yang memberikan dana untuk penanaman bibit mangrove.

Dari sebagain dana tersebut, sebagian dialokasikan untuk pembuatan jembatan yang menjadi penghubung antara RT satu dengan RT lainnya. Karena memang jarak dari RT satu dengan RT lainnya terdapat beberapa rumah warga yang lokasinya berda dibersebrang rumah warga yang terletak di RT lain, adanya sungai kecil menjadi pemisah antara rumah warga di RT satu dengan rumah warga yang tergabung di RT lain.

Ketiga, sejak hadirnya Komunitas Save Mugo di tengah-tengah masyarakat Kampung Beting, ada beberapa perubahan yang dirasakan oleh masyarakat sekitar. Sejak adanya kontribusi dari Komunitas Save Mugo, terdapat beberapa jembatan yang diperbaiki, sehingga warga tidak sulit lagi 
jika ada keperluan, dan harus melewati sungai yang menjadi pemisah antara rumah warga yang berbeda RT. Selain itu, terdapat perahu yang menjadi pengganti ambulan bagi warga, kini wrga tidak begitu khawatir jika ada anggota keluarganya yang harus ditindak lanjuti dalam pengobatan secara medis, meski hal itu terjadi pada saat musin penghujan. Karena dengan adanya perahu warga Kampung Beting tetap bisa membawa keluarganya yang sedang sakit dengan menggunakan perahu melewati kali Citarum.

Selain itu, terdapat juga fasilitas umum yaitu MCK yang dipergunakan warga untuk mengambil air bersih, hal ini disebabkan masih ada beberapa warga yang belum memiliki sumur sebagai sumber untuk mengambil air bersih.

Warga Kampung Beting menggunakan sumur bor sebagai sumber air untuk digunakan dalam aktivitas sehari-hari, seperti mandi, mencuci piring dan pakaian dan kegiatan sehari-hari lainnya. Karena kadar air sumur yang sedikit asin, membuat warga menggunakan air sumur hanya untuk mandi dan mencuci, sedangkan untuk air minum dan memasak warga menggunakan air galon, dan bila musim penghujan warga menggunkan air hujan yang telah ditampung dalam wadah, untuk air minum dan memasak. Namun belum semua warga memiliki sumur bor, maka dengan adanya MCK umum, hal ini dapat membantu warga yang memang tidak memiliki sumur, sehingga warga tetap bisa menggunakan air bersih untuk kebutuhan seharihari.

Selain jembatan, perahu dan MCK. Terdapat juga fasilitas umum lainnya yaitu TPQ, dimana selain untuk belajar mengaji TPQ juga digunakan untuk kegiatan lainnya, seperti tempat untuk anak-anak belajar membaca. Letak TPQ yang jaraknya berada di samping tempat produksi olahan mangrove, menjadi perhatian bagi para komunitas lain yang berkunjung ke tempat pembuatan olahan mangrove. Karenanya terdapat beberapa buku, dan alat tulis lainnya untuk medung kegiatan belajar dan mengajar di TPQ.

\section{Hasil Pemberdayaan Lingkungan}

Keberhasilan Komunitas Save Mugo dalam upaya pengembalian ekosistem hutan mangrove. Hal ini berawal dari hilangnya hutan mangrove yang dialihkan menjadi tambak, sehingga mengakibat Kampung Beting 
mengalami abrasi, karena abrasi yang cukup besar hingga mengerus pemukiman warga sekitar. Dampak yang ditimbulkan ialah hilangnya sumber mata pencaharian dan tempat tinggal warga. Dalam hal ini Komunitas Save Mugo menyusun perencanaa untuk membantu menyelesaikan permasalahan warga Kampung Beting, seperti yang terdapat dalam model pemberdayaan yaitu perencanaan sosial (Social Planning Model). Dari beberapa data temuan lapangan, penelitian ini menggambarkan adanya pemberdayaan masyarakat dengan perbaikan ekosistem mangrove, melalui ekosistem mangrove terbentuklah pemberdayaan dibidang ekowisata dan pemberdayaan ekonomi kreatif.

Kemudian persoalan lingkungan yang ada di Kampung Beting, adanya langkah-langkah pemberdayaan yang bertujuan mengubah perilaku warga untuk membangun kesadaran dan kepedulian terhadap lingkugan. Pada awalnya, Kampung Beting merupakan satu wilayah dimana terdapat banyak pohun mangrove yang tumbuh subur, sehingga warga memiliki penghasilan laut melimpah. Namun pada tahun 2005 terjadi abrasi yang cukup besar yang menghilangkan tambak dan sebagian pemukiman warga. Hal ini terjadi akibat kurangnya kesadaran warga terhadap pentingnya hutan mangrove, dimana hutan mangrove merupakan keberlangsungan kehidupan mereka sebagai masyarakat pesisir.

Penggundulan hutan mangrove karena warga hendak menjadikan sebagian wilayah hutan mangrove sebagai tambak, sehingga terjadi penebangan secara besar-besaran. Dampak dari penggundulan hutan mangrove ini dirasakan warga pada tahun 2005 setelah terjadinya abrasi yang cukup besar, kurang lebih setinggi 60 sampai 70 meter.

Dalam upaya pemberdayaan masyarakat, masyarakat didorong untuk mampu mengelola dan memanfaatkan sumber daya yang dimiliki secara optimal dengan didampingi fasilitator ${ }^{15}$. Maka untuk meningkatkankan kesadaran warga Kampung Beting mengenai pentingnya menjaga hutan mangrove. Komunitas Save Mugo memberikan edukasi kepada warga melalui pembentukan pokdarwis Alipbata. Dimana kelompok

\footnotetext{
15 Tantan Hermansah, Pemberdayaan Masyarakat Perspektif Kultural Konsep E Praktek (Jakarta: UIN Jakarta Press, n.d.).
} 
Alipbata yang akan melanjutkan program secara mandiri. Pokdarwis Alipbata merupakan kelompok masyarakat yang memiliki kesadaran untuk menjaga lingkungan, sehingga Alipbata yang akan memberikan penyadaran kepada warga lain untuk ikut berkontribusi dalam menjaga kelestarian hutan mangrove.

Permasalahan yang dialami oleh warga Kampung Beting, membuat Komunitas Save Mugo melakukan program perbaikan ekosistem mangrove untuk mengembalikan hutan mangrove Muara Gembong seperti sedia kala. Maka dalam hal ini, Save Mugo melakukan pemberdayaan seperti apa yang dikatakan Subejo dan Suprianto ${ }^{16}$. Bahwa pemberdayaan masyarakat ialah upaya untuk memfasilitasi masyarakat untuk mengelola dan memberi keputusan dalam sumber daya lokal, sehingga masyarakat mampu secara ekonomi, ekologi dan sosial ${ }^{17}$. Dalam hal ini peneliti menemukan data lapangan, bahwa melalui perbaikan ekosistem hutang mangrove terbentuklah pemberdayaan lain yaitu penghasilan tambahan bagi para petani bibit mangrove dan pemberdayaan dibidang ekowisata.

\section{Penghasilan Tambahan}

Sejak dilakukan perbaikan ekosistem mangrove, terdapat beberapa komunitas lain dan juga PT yang ikut berkontribusi melakukan penanaman mangrove di Kampung Beting. Selama penanaman mangrove, bibit mangrove yang akan ditanam diperoleh melalui warga yang tergabung dalam petani bibit mangrove. melalui pemesanan bibit mangrove sebagian warga yang tergabung dalam petani tersebut bisa memproleh hasil tambahan diluar propesinya sebagai petani tambak dan nelayan.

Semakin banyak penanaman pohon mangrove maka warga yang tergabung dalam petani tersebut semakin memiliki peluan untuk para petani itu mendapatkan penghasilan tambahan. Dengan harga perbibitnya sebesar Rp.7000 per satu bibit mangrove.

\footnotetext{
16 Totok Mardikanto and Poerwoko Soebianto, Pemberdayaan Masyarakat Dalam Perspektif Kebijakan Publik (Bandung: Alfabeta, 2015).

${ }_{17}$ Mardikanto and Soebianto.
} 


\section{Pemberdayaan Ekowisata}

Pemberdayaan ekowisata terbentuk dari keperdulian warga terhadap lingkungan, dampak yang ditimbulkan dari hilangnya hutan mangrove membuat sebagian warga Kampung Beting kini tersadar tentang pentingnya fungsi hutan mangrove. Setelah program penanaman bibit mangrove berjalan dengan baik, maka hutan mangrove perlahan mulai tumbuh seperti sedia kala. Artinya, hewan-hewan yang hidup dilingkungan hutan mangrove menemukan kembali habitatnya dan mulai kembali berkembang biak. Berdasarkan hal ini Komunitas Save Mugo dan pokdarwis Alipbata melakukan program pemberdayaan yang berkelanjutan dibidang ekowisata. Pemberdayaan ekowisata bukan hanya bertujuan untuk memperbaiki perekonomian warga, tetapi juga sebagai bentuk kesadaran warga untuk tetap menjaga kelestarian hutan mangrove.

\section{Pemberdayaan Ekonomi Kreatif Kelompok Bahagia Berkarya}

Kontribusi yang berupa terbukanya peluang usaha untuk ibu-ibu rumah tangga yang dijalankan oleh Kebaya, merupkan salah satu program pemberdayaan yang diberikan oleh Komunitas save Mugo kepada masyarakat. Membuka peluang usaha untuk ibu-ibu, merupakan tujuan untuk mengembangkan kemampuan masyarakat yang terdapat dalam model pemberdayaan masyarakat yaitu Model Pembangunan lokal (Locality Development). Hal demikian dapat membantu meningkatkan perekonomian warga dengan penghasilan yang didapatkan oleh ibu-ibu Kebaya.

Pemberdayaan ekonomi kreatif ini merupakan keberlanjutan dari pemberdayaan dibidang ekowisata. Pemberdayaan ekonomi kretaif melibatkan sebagian ibu-ibu rumah tangga, yang pada awalnya tidak memiliki pekerjaan untuk membantu perekonomian keluarga. Dalam program ini ibu-ibu Kebaya membuat olahan dengan memanfaatkan pohon mangrove. Seperti apa yang dikatakan oleh Robert Lucas, bahwa ekonomi kreatif merupakan konsep yang dijalankan oleh orang-orang yang memiliki kreativitas dengan mengandalkan kemampuan dari ilmu pengetahuannya sebagai kekuatan untuk melakukan aktivitasnya. Cony Semiawan pun 
mengatakan bahwa kreativitas merupakan kemampuan seseorang untuk membuat produk baru ${ }^{18}$.

Melalui pemberdayaan ekonomi kretaif ibu-ibu Kebaya membuat produk dari bahan dasar mangrove, dimana pada awalnya pohon mangrove hanya difungsikan sebagai mencegah terjadinya abrasi. Kini fungsi pohon mangrove bertambah nilai gunanya bagi warga Kampung Beting, yaitu memiliki nilai ekonomis melalui produk yang dibuat oleh ibu-ibu Kebaya.

Tujuan lain dari pemberdayaan ekonomi keratif adalah agar ibu-ibu rumah tangga bisa memiliki penghasilan sendiri, sehingga dapat membantu suaminya dalam mencukupi kebutuhan sehari-hari. Sebelum membuat olahan mangrove seperti saat ini, Kebaya terlebih dahulu mengikuti beberapa pelatihan untuk membuat produk olahan yang memliki standar gizi dan bersertivikat halal, selain itu dengan mengikuti beberapa pelatihan kini Kebaya juga mendapatkan beberapa menghargaan yang menunjang karirnya dalam bidang ekonomin kreatif.

\section{SIMPULAN}

Hadirnya Komunitas Save Mugo sejak tahun 2013 ini memang cukup menimbulkan berbagai perubahan dalam kehidupan sosial warga Kampung Beting. Selain peruabahan sosial, hadirnya Komunitas Save Mugo juga memberikan kontribusi dalam kehidupan ekonomi warga. Berikut beberapa catatan analisis atas temuan di Kampung Beting tersebut:

Pertama, kontribusi yang dilakukan Komunitas Save Mugo di Kampung Beting, telah membuka peluang usaha untuk ibu-ibu rumah tangga. Ibu-ibu yang tergabung dalam Kebaya kini bisa memiliki penghasilan sendiri. Dimana penghasilannya bisa digunakan untuk membantu memenuhi kebutuhan keluarganya bahkan ibu-ibu Kebaya bisa memenuhi kebutuhan sandangnya.

Kedua, hasil pemberdayaan yang dilakukan adalah pemberdayaan ekowisata sebagai tindak lanjut dalam punya pelestarian hutan mangrove. Melalui persoalan lingkungan yang dialami oleh warga Kampung Beting,

18 Buchari Alma, Kewirausahaan Untuk Mahasiswa Dan Umum (Bandung: Alfabeta, 2013). 
mulai timbulah langkah-langkah untuk menyelamatkan dan mengembalikan hutan mangrove yang rusak. Salah satunya dengan memberikan edukasi kepada warga dan membentuknya pokdarwis Alipbata.

Ketiga, pemberdayaan ekonomi kreatif telah membantu meningkatkan kesejahteraan warga Kampung Beting. Seperti sejak bergabungnya Kebaya di UKM dan UMKM, Kebaya mulai mengikuti beberapa pameran hingga mendapatkan beberapa penghargaan dengan kategori yang berbeda.

\section{DAFTAR PUSTAKA}

Alma, Buchari. Kewirausahaan Untuk Mahasiswa Dan Umum. Bandung: Alfabeta, 2013.

Arkwrigh, Darius, and Irena Septianita Kaomaneng. "Mangrove Ecotourism Development on Kakaralamo Island North Halmahera: Community Perception, Participation and Development Strategies." IOP Conf. Series:

Earth and Environmental Science 175 (2018).

“Data Progress Movement Save Mugo 2018," n.d.

Hakim, Luchman, Dian Siswanto, and Nobukazu Nakagoshi. "Mangrove Conservation in East Java: The Ecotourism Development Perspectives." The Journal Of Tropical Life Science 7, no. 3 (2017): 277-85.

Hanifah, Abu, and Kamaruddin Eddiwan. "Community-Based Mangrove Forest Management Action in Rangsang Region, District of Kepulauan Meranti, Riau," 2018.

Henri, and Seta Ardiawati. Ecotourism Development Of Munjang Mangrove Forest And Conservation Efforts Based On Community Approach, 2020.

Mardikanto, Totok, and Poerwoko Soebianto. Pemberdayaan Masyarakat Dalam Perspektif Kebijakan Publik. Bandung: Alfabeta, 2015.

Meleong, Lexy J. Metodologi Penelitian Kualitatif. Bandung: PT Remaja Rosdakarya, 1991.

Paruntu, Carolus P., Agung B. Windarto, and Movrie Mamesah. "Mangrove

Dan Pengembangan Silvofishery Di Wilayah Pesisir Desa Arakan

Kecamatan Tatapaan Kabupaten Minahasa Selatan Sebagai Iptek Bagi

Masrakat." Jurnal LPPM Bidang Sains Dan Teknologi 3, no. 2 (2016).

Purwowibowo, and Nur Dyah Gianawati. “Kearifan Lokal Dalam Pelestarian 
Hutan mangrove Melalui Community Development." Dalam Jurnal Bina Hukum Lingkungan 1, no. 1 (2016).

Salampessy, Messalina L, Indra G Febryano, Edwin Martin, Martha E. Siahaya, and Renold Papilaya. "Cultural Capital Of The Communities In The Mangrove Conservation In The Coastal Areas Of Ambon Dalam Bay, Moluccas, Indonesia." International Conference on Tropical and Coastal Region Eco-Development 2014, 2014.

Sulistyorini, Iin Sumbada, Erny Poedjirahajoe, and Lies Rahayu Wijayanti Faida Ris Hadi Purwanto. "Social Capital in Mangrove Utilization for Silvofishery: Case Study in Kutai National Park, Indonesia." Jurnal Manajemen Hutan Tropika 24, no. 2 (2018): 60-69.

Sutrisno. "Pemberdayaan Dan Partisipasi Masyarakat Pesisir Dalam Pengembangan Tanaman Mangrove Di Kabupaten Pati." Jurnal Bina Praja 7, no. 1 (2015).

Takarendehang, Roberto, Calvyn F.A. Sondak, Erly Kaligis, Deslie Kumampung, Indri S. Manembu, and Unstain N.W.J. Rembet. “Kondisi Ekologi Dan Nilai Manfaat Hutan mangrove Di Desa Lansa, Kecamatan Wori, Kabupaten Minahasa Utara." Jurnal Pesisir Dan Laut Tropis 2, no. 1 (2018).

Tantan Hermansah. Pemberdayaan Masyarakat Perspektif Kultural Konsep \& Praktek. Jakarta: UIN Jakarta Press, n.d.

Valenzuela, Roswin B, Youn Yeo-Chang, Mi Sun Park, and Jung-Nam Chun. “Local People's Participation in Mangrove Restoration Projects and Impacts on Social Capital and Livelihood: A Case Study in the Philippines." In Forest 11 (2020): 580. 